\title{
International Financial Institution Governance: The Role of Shareholders
}

\author{
Whitney Debevoise*
}

\begin{abstract}
This chapter addresses the integral role of shareholders in the good governance of international financial institutions. It is divided into five parts, beginning firstly with consideration of the generally held concerns of all shareholders, notably, veto rights, the powers of governors, the role of executive directors, and the essential leadership responsibilities of an institution's president. Second, the relationship between shareholders, good governance and the mobilizing of resources, in particular funding the institution effectively and developing a sustainable financial model is examined. Third, the chapter looks at the indispensable role of shareholders in maintaining a domestic legal environment conducive to the success of an international financial institution. Fourth, it highlights the role that shareholders may play in inter-institutional relationships. Fifth, and by way conclusion, this chapter argues that good shareholder governance is crucial to the success of all international financial institutions, both old and new.
\end{abstract}

The inaugural Asian Infrastructure Investment Bank (АІІВ) legal conference held in Beijing in October 2017 had Good Governance and Modern International Financial Institutions as its theme, thereby transmitting an important message about AIIB's ethos and aspirations as a multilateral development bank. Against that background, this chapter addresses the role of shareholders in good governance at an international financial institution (IFI). Shareholders come in several sizes-large, medium and small-and types (borrowers and non-borrowers). ${ }^{1}$ Regardless of size or type, IF I shareholders share certain

* Partner, Arnold \& Porter, Washington, D.C.; US Executive Director, The World Bank, 2007-2010.

1 At the World Bank, not all countries borrow; when their GDP per capita reaches a threshold, they "graduate." АІгв all members are currently eligible to borrow regardless of their per capita income. 
common interests. But not all shareholders are equal, so this chapter addresses both shareholder concerns generally as well as more specific interests, particularly those of the largest shareholder of an IFI, including shareholders with veto rights.

There can be several types of shareholder representatives, usually known as governors and directors, or as they are frequently called-executive directors. Their respective functions are set out in an IFI's Articles of Agreement, but their overall perspective on governance can be rooted in the same concerns. ${ }^{2}$ Some of the key concerns include effective leadership for the organization, the financial health and sustainability of the institution, mobilizing resources when needed, fiduciary concerns for taxpayer money, providing a conducive domestic legal environment for the IFI, promoting the bank domestically, respecting the international character of the bank, and attention to the bank's relationship with other organizations, domestic and international. Some shareholders are also driven by a desire to maximize resources for a particular constituency, but that factor does not change many of the basics. Among those basics are recurring themes such as reputation risk, transparency and the proper balance between politics and economics.

\section{General Shareholder Concerns}

One lens for understanding shareholder concerns at an IFI is the Articles of Agreement of the institution in question. What responsibilities are considered so significant that shareholders reserve the power to act for their most senior representatives-usually called governors and usually cabinet ministers or central bank governors? Similarly, what are the responsibilities delegated by governors to executive directors and what are the responsibilities further delegated to bank management? Finally, what are the decisions considered so significant that one single shareholder or small group of shareholders can block or veto action?

\subsection{Veto Rights}

Interestingly, at the International Bank for Reconstruction and Development (World Bank), unlike the International Monetary Fund, veto rights are

2 There can be some differences, however. Governors may be somewhat more inclined to think largely in representational terms, whereas directors who represent multiple countries may give slightly more weight to fiduciary concerns. 
extremely limited, and the veto is not a factor in the daily life of the Bank. The US, the largest shareholder of the International Bank for Reconstruction and Development, can veto amendments to the Articles of Agreement. This provision makes sense when viewed from the perspective of the Bank's financial model which is built on a small amount of paid-in capital, callable capital and a sizeable amount of borrowing in the capital markets. At the time of the Bank's founding, of course, the target financial market was Wall Street, because the world's other major markets had yet to recover from World War II. In order to win the confidence of Wall Street, it was important for investors to understand that the financial model would not change. This model was anchored in the Articles of Agreement, and investors wanted assurance that the Articles would not change. Accordingly, the threshold for amendment of the Articles of Agreement was set at 85 percent, giving the US a veto. ${ }^{3}$ The AIIв has adopted this approach in its Articles of Agreement, giving its current, largest shareholder a veto over amendment of the Articles. ${ }^{4}$

Increases in the number of directors at the World Bank require a four-fifths majority of the total voting power, so the United States, which currently holds less than 17 percent, cannot veto any such increase. Indeed, when the World Bank increased the number of its directors from 24 to 25 in 2010, the possibility of a US veto was not a factor.

Increases in World Bank capital require a three-fourths majority of the total voting power, so the US cannot veto capital increases. All shareholders are given preemption rights but no shareholder is "obligated to subscribe any part of the increased capital." Furthermore, a simple majority determines the terms of subscription, so the US has no veto on that subject.

Loans and guaranties are approved by a simple majority of the voting power. Once again, the US has no veto. If the US opposes a loan or guaranty it must either convince Bank management not to bring the loan forward to the Board or build a majority coalition to stop the loan. The need to build coalitions at an IFI, particularly when it is for a positive purpose, is a key element in IFI governance and may explain why so many decisions are taken by consensus with no formal polling. On the other hand, most IF Is have weighted voting and are therefore able to move forward after a healthy debate.

3 Articles of Agreement of the International Bank for Reconstruction and Development (dated 27 December 1945, as amended through 2012) (World Bank Articles of Agreement), art $\operatorname{VIII}(\mathrm{a})$.

4 Articles of Agreement of the Asian Infrastructure Investment Bank (dated 29 June 2015, entered into force 25 December 2015) (AIIB Articles of Agreement), arts 28 and 53(1).

5 See n 4, World Bank Articles of Agreement, art II, s 3 (c). 


\subsection{Powers of Governors}

The powers reserved to the Governors at the World Bank comprise a short list:

1. Admission of new members and the conditions for their admission.

2. Increases or decreases in capital stock.

3. Suspension of a member.

4. Deciding appeals of interpretations of the Articles given by the Executive Directors.

5. Arrangements to cooperate with other international organizations (other than informal arrangements of a temporary and administrative character).

6. A decision to suspend permanently the operations of the Bank and to distribute its assets.

7. Determining the distribution of the net income of the Bank. ${ }^{6}$

In practice, this list is even shorter, as for example, the distribution of net income is essentially decided by the Executive Directors, albeit with input from capitals, prior to the submission to the Governors for formal approval. Further, although the Articles provide that the Governors shall determine the salary and terms of the contract of service of the President, in practice, this task is undertaken by the Executive Directors.

The reserved powers of the АІІв Board of Governors are similar, although they do differ in one important respect. Selection of the President of the World Bank is formally in the hands of the Executive Directors, whereas at the AIIB, the Governors hold this power. Since Executive Directors at the World Bank cast a single vote on behalf of a constituency, ${ }^{7}$ a member could "vote for" a candidate it in fact opposes, whereas at the AIIB, a member could always oppose a candidate it did not want.

\subsection{Executive Directors}

The powers of the Executive Directors of the World Bank include responsibility for the conduct of the general operations of the Bank and for that purpose, they exercise all the powers delegated to them by the Board of Governors. These delegated powers are extensive since the Governors have essentially retained only the powers provided in the Articles. This is appropriate since Governors are high-ranking officials in national governments or central banks and already have full agendas.

6 See n 4, World Bank Articles of Agreement, art v, s 2(b).

7 Ibid, World Bank Articles of Agreement, art v, s 4(g). 


\section{$1.4 \quad$ Effective Leadership-The President}

The allocation of power between the Executive Directors and the President of the World Bank has evolved since the formation of the Bank. Formally, the President is the "chief of the operating staff of the Bank"8 and conducts, "under the direction of the Executive Directors, the ordinary business of the Bank." ${ }^{\prime 9}$ "Subject to the general control of the Executive Directors," the President is "responsible for the organization, appointment and dismissal of the officers and staff." 10

The division of responsibility between the President and the Executive Directors was largely defined in negotiations between John Jay McCloy and the Executive Directors as he was recruited to serve as President. The allocation was formalized with the Board's Committee on Organization in June 1947. Essentially, the Executive Directors are responsible for policy decisions; however, all policy proposals must originate with management. This arrangement permits the President and staff to execute on policies and guidance provided by the shareholder representatives. It also lends stability to the institution since policies once adopted should be consistently applied and not be constantly reevaluated. It also helps to reduce to a certain extent the political component of decision-making because management can justify its actions as the even-handed application of approved policy.

The most important task of shareholder representatives is the selection of the president or head of the organization. Regardless of prevailing conventions with respect to nationality or leadership eligibility or rotation, the power to select the head of the organization must be exercised responsibly. A failure to do so can lead to paralysis of the institution and undermine its core mission.

Once the shareholders make their choice, they need to allow the head to lead. Shareholders can make suggestions and advocate. That is why they have representatives, be they governors or directors, but they must not micromanage. In this regard, IFIs should be no different than any other organization with a board of directors and management.

The Trustee's Handbook of the American Association of Independent Schools, for example, states that the most important function of a trustee is the selection and annual review of the head of the organization. So, from the smallest non-profit to the largest IFI, selection of the head of the organization is a key governance responsibility.

The recent evolution on this subject is reflected in AIIB's Articles of Agreement which specifies that election shall be through an "open, transparent and

\footnotetext{
8 See n 4, World Bank Articles of Agreement, art v, s 5(b).

9 Ibid.

10 Ibid
} 
merits-based process."11 That said, the process is an election with weighted voting and not free from politics. For example, one relevant criterion may appropriately be the ability of the president to secure crucial support from the largest shareholder(s). The key is for the shareholders with the most power to exercise that power responsibly by reaching out to other shareholders in an open, transparent way and promoting the best candidate available. Interestingly, the АІІв Articles of Agreement extend the notion of an open, transparent and merits-based process to the selection of Vice-Presidents. ${ }^{12}$

Other aspects of good governance that are present in the private and nonprofit sectors, such as the annual review of the head of the organization and succession planning, deserve more thought when considering an IFI. There may be sound political reasons why these concepts and tools cannot be deployed at IFIs, but more thought should be given to how to use annual meetings, development committee meetings and strategic planning exercises to achieve some of the same results as an annual goal setting and head-review process.

The other key dimension in the intersection between Executive Directors and the President and senior management is the degree of delegated authority, particularly for financings. Normally delegation is handled by establishing numerical thresholds for operations, with the Directors reserving the right to withdraw delegated authority for a specific transaction and pull it for board discussion. The theory is that policy issues can lurk even in smaller operations. On the other hand, the power to pull projects for full board discussion may have the perverse effect of lowering management's own internal controls because some may assume that the directors are, in fact, examining every transaction closely, even those proposed under delegated authority. In practice, the sheer volume of the documentation for such operations may militate against such careful scrutiny. Ultimately, the Directors and management must earn each other's trust in order to achieve the appropriate and most efficient level of delegation for the institution.

\section{Mobilizing Resources}

\section{1 $\quad$ Funding}

Shareholders also have a duty to foster an institution that can fulfill its stated purposes. This essentially involves resources. Resource mobilization starts

11 See n 5, AIIB Articles of Agreement, art 29(i).

12 Ibid, АIıв Articles of Agreement, art 3o(i). 
with capital or grants but does not end there. ${ }^{13}$ Shareholders can make an important contribution by making sure that the institution can access domestic capital markets and do so efficiently. This may involve accommodations in domestic securities laws and regulations. For example, in the US, the IBRD arm of the World Bank benefits from a statutory exemption from the registration requirements of the Securities Act of 1933 and the reporting requirements of the Securities Exchange Act of $1934 .{ }^{14}$ The same applies for the International Finance Corporation ${ }^{15}$ and other multilateral development banks in which the US is a shareholder, the Asian Development Bank, the Inter-American Development Bank, the African Development Bank and the European Bank for Reconstruction and Development. Interestingly, when the International Development Association (IDA) arm of the World Bank Group, went to market for the first time in March 2018, it accessed the Rule 144A/Regulation S market. Rather than registering securities with the SEC on Schedule B, which is what the European Investment Bank ${ }^{16}$ and a number of other multilateral development banks do, IDA decided to use the institutional investor market until an explicit exemption can be arranged.

Another important source of financial support is grants. IDA, for example, depends on a triennial pledging process. For many years, the US led by example, making the largest donations to IDA. In recent IDA rounds, other donors have surpassed the US, although since inception, the US has contributed more than any other nation to IDA. The United Kingdom's leading donor position in IDA-16 reflected, in part, a national commitment to spend 0.7 percent of GDP on Official Development Assistance in keeping with its Millennium Summit and other commitments. Since IDA provides leverage of nearly 10:1 for the UK, a strong IDA contribution also leveraged the resources of the UK. With the decision in IDA-18 to permit IDA to access the market, leverage should increase for all IDA donors.

As important as the pledging process for IDA and other soft-loan windows of MDBs may be, following through on pledges is equally important. In the US,

13 Shareholders can also induce donors to create trust funds, although sound administration of trust funds and their incorporation into an IFI work program have their own governance issues.

14 Bretton Woods Agreements Act, 22 U.s.c. $\$ 286 \mathrm{k}-1$.

1522 U.s.c. $\$ 282 k$. See e.g., New Zealand, Securities Act (International Finance Corporation). Exemption Notice 2009, <http://www.legislation.govt.nz/regulation/public/2009/ 0297/12.0/whole.html> accessed 14 May 2018.

16 See e.g., European Investment Bank Registration Statement under Schedule B of the Securities Act of 1933, <https://www.sec.gov/Archive/edgar/data/33745/oooo95015718000325/ forms-b.htm > accessed 21 March 2018. 
this requires legislative approval of the grant. Theoretically, legislation authorizing the US contribution to IDA (or any other grant to the soft-loan window of an international financial institution) is required. Once authorized, the current year's contribution must also be included in appropriation legislation on an annual basis throughout the three-year IDA funding period. At times, the Congress combines the authorization and the current-year appropriation. At times, it dispenses with the authorization altogether. ${ }^{17}$ Each is important, however, because each originates in a different committee of the House and of the Senate which can give the Executive Branch several levers to pull in obtaining legislative approval.

At times, the US Congress attaches conditions to IDA authorizations, and some of the conditions or mandates extend beyond IDA to IBRD and IFC. Some involve voting instructions to US shareholder representatives. For example, the Congress has directed the US Executive Director at the World Bank to oppose Cuban membership and the US Treasury to withhold US payments if an IFI should approve assistance to Cuba. ${ }^{18}$ Others involve policy directives instructing the US Executive Director to advocate certain positions. For example, at times, the Congress has instructed the US Executive Director of the World Bank to use the voice of the US to advocate for the adoption of particular procurement policies and internal justice reforms. The Congress also directs the US Executive Director how to vote on certain matters. ${ }^{19}$ For example, the Congress has instructed the US Executive Director at the World Bank to use the vote of the US to oppose loans to countries designated as major producers of illicit drugs, ${ }^{20}$ supporters of international terrorism, ${ }^{21}$ nuclear proliferators, ${ }^{22}$ human traffickers ${ }^{23}$ and production of palm oil, sugar or citrus crops for export if the financial assistance would cause harm to US producers. ${ }^{24} \mathrm{~A}$ well-known example of a voting directive is the Pelosi Amendment, which prohibits the U.S Executive Director from voting for any category A environmental project

17 See also Louis Fisher, "The Authorization-Appropriation Process in Congress: Formal Rules and Informal Practices" (1979) 29 Cath. U.L. Rev. 51 (surveying Congressional use of authorization and appropriation legislation).

18 Public Law No. 104-114 (1996).

19 Although such directives may be unconstitutional on separation-of-powers grounds, no Executive Director or Administration has ever challenged such a directive, beyond a reservation of rights in a Presidential signing statement.

$20 \quad 22$ U.S.C. $\$ 2291 j(a)(2)$.

2122 U.S.C. $§ 262 p-4 q$.

2222 U.S.C. $\$ 6302$.

2322 U.S.C. $\$ 7107$.

2422 U.S.C. $\$ 262$ g. 
for which the environmental impact statement has not been posted on the World Bank's website at least 120 days prior to the date of the vote. ${ }^{25}$

Some such policy directives have resulted in substantive changes in policies at the multilateral development banks. ${ }^{26}$ For example, most multilateral financial institutions in which the US is a member now have an accountability mechanism such as the Inspection Panel at the World Bank. ${ }^{27}$ Such units investigate claims by parties adversely affected by Bank projects, for example by a forced resettlement, that the Bank has not followed its own policies for addressing such situations. In the case of the World Bank, the Inspection Panel resulted from US advocacy following Congressional directives in IDA appropriations legislation.

The governance aspect of such shareholder action may be seen as problematic for a multilateral. What if every shareholder conditioned its grants or capital contributions to the adoption of particular policies? Also, are such legislative directives not in violation of provisions such as Article III, Section 2 of the World Bank Articles of Agreement, which provides that "each member shall deal with the Bank only through its Treasury, central bank, stabilization fund or other similar fiscal agency," namely through its Governor and the respective Executive Director for its constituency? On the other hand, each country may establish its own internal procedures for establishing policy priorities and instructing its shareholder representatives. One might question whether voting instructions are helpful because they might interfere with the shareholder representative's ability to negotiate acceptable solutions. On the other hand, since multilateral development bank grants and loans involve public money, some political organs may want to be in a position to say that its representatives opposed the use of taxpayer funds for project $\mathrm{X}$ or initiative $\mathrm{Y}$. At times, though, particularly when it comes to major institutional initiatives, it may be useful for all shareholder representatives to know that when the shareholder representatives from the executive branch of a large shareholder speak, they are speaking not only on behalf of the executive branch of that member but also on behalf of the legislative branch which controls the member's grants and capital contribution to the institution. For some this will be seen as leadership; for others, interference. For the good of the institution and of the shareholder in question, such techniques should be used responsibly and not overused.

25 International Development and Finance Act of 1989, Public Law No. 101-240, 103 Stat. 2492, 2511 (codified as amended at 22 U.s.C. 262m-7 (1990)).

26 See Bowles and Karmos, "Environmental Reform at the World Bank: The Role of the US Congress" (1995) 35 Va. J. Int'l L. 777.

27 Resolution No. IBRD 93-10 and Resolution No. IDA 93-96. 


\subsection{A Sustainable Model}

Resource mobilization also involves the development and maintenance of a strong, sustainable financial model. After all, the institution must earn the trust of the financial community. Rating agencies and lenders are looking for strong shareholder commitment in the form of both paid-in and callable capital but also sound lending and risk management policies. Similarly, shareholders need to promote policies that will induce donors to make grants, for example to IDA or other trust funds. Strong fiduciary policies and controls also figure in the equation. Together all of these produce a strong, sustainable financial model that inspires confidence, produces a high rating - triple-A in the cases of the World Bank and АІІв - and access to markets in the required amounts and at the lowest rates possible.

A strong, sustainable financial model starts with a solid balance sheet with solid assets. This requires prudent investment decisions. As with all banks, good loans result from a complex of credit policies for both sovereign lending and corporate debt and equity, as the case may be. Credit allocation is key, as are single borrower, country and sectoral limits. The institution must have a skilled treasury function to invest the funds not immediately needed in operations, including policies on permitted investments and the use of derivatives. There should also be a well-run pension system for employees, likely a defined contribution plan and not a defined benefit plan. Appropriate policies are needed for the establishment and use of reserves and for provisioning. Pricing policies for loans, guarantees, derivatives and equity investments are important.

The liability and capital sections of the balance sheet also figure in the equation. The institution needs a borrowing plan and attention to debt management, including attention to the debt profile and to currency and asset-liability matches. Capital ratios also require attention and constant review. All of these policies should be of concern to shareholders, particularly to the largest shareholders with the largest callable capital. At the same time borrowing countries have an interest in the extent to which the balance sheet can be stretched without increasing the cost of IFI loans.

Another important component of a sustainable financial model involves the budget. Here shareholders need to keep an eye on budget policies and the budget process. This involves administrative expenses, including particularly salary structures and benefits, including training, pension, and medical benefits, as well as travel and home-leave policies and procurement for the institution itself. The information technology spend needs to be understood and monitored. Adequate resources for fiduciary controls, internal and external audit, accountability and institutional integrity mechanisms are all important, as are functions inherent in a development bank such as economic and 
operational research, project monitoring and results measurement. Finally, external relations and the management of the institution's real estate needs cannot be neglected.

Some development institutions have been known to place some expenses which most would consider ordinary business expenses below the line. Nevertheless, responsible shareholders have an interest in having the income statement look as normal as possible to the market and to taxpayers.

A key tool for shareholders lies in the budget process. This starts with discussions about medium-term strategy, which can be part of a mechanism for deciding priorities and allocating resources accordingly. There can be a tendency at multilateral institutions to resolve difficult discussions about resource allocation by attempting to please all constituencies by spreading resources thinly across many uses with the result that some are underfunded. Here large shareholders need to support focus and act responsibly when advancing their own policy initiatives.

\section{Conducive Legal Environment}

Another aspect of good governance and shareholder responsibility concerns providing a conducive domestic legal environment for the institution. As mentioned above, if the IFI desires to access the capital markets of a shareholder, measures can be adopted to facilitate access to markets and to make access as efficient as possible, while protecting investors. The same applies to measures to facilitate the IFI's lending function, a key activity that should not be impeded by domestic registration or regulatory requirements. Modern IF Is may have sizeable treasuries that need to be invested and managed, including with the use of derivatives. They should be permitted to do so without being subjected to domestic registration, central clearing and margin requirements. ${ }^{28}$

Shareholders can also assist IFIs through the extension to the institutions and their personnel of privileges and immunities. The Articles of Agreement of the World Bank and AIIB call for no less. ${ }^{29}$ The Articles of Agreement and

28 The US Commodity Futures Trading Commission and the federal banking agencies have accorded the World Bank, the other IFIs in which the US is a shareholder and certain other IFIs recognized in Europe suitable exemptions from these requirements. See CFTC definition of major swap participant, CFTC rule on central clearing and Federal Reserve Board regulation on margin.

29 See World Bank Articles of Agreement, art VII, s 10 (n 4), АІІв Articles of Agreement, Article 44(2) (n 5). See also Jamaica, The International Finance Corporation Agreement Act 3 of 1964 (5 March 1964). 
headquarters agreement of an IFI may provide for tax and customs duty exemptions, currency transfer, special immigration status, labor law regimes and other accommodations for the organization, its shareholder representatives, employees, families and members of their households. The archives of the organization and its bank accounts should be protected from interference by governments and third parties. This can be accomplished through the incorporation of the Articles into domestic law, either expressly or as a self-executing treaty or by adoption of domestic legislation and regulations providing the necessary privileges and immunities.

Another important area of shareholder support concerns security and local law enforcement. Cybersecurity is crucial for IFIs given the extensive data about members and projects in their possession and combat against cybersecurity often requires healthy interaction with domestic agencies. Support from shareholders in this area can be invaluable.

\section{Domestic Promotion of the IFI}

Domestic promotion of the IFI involves outreach to the Executive and Legislative Branches as well as the general population. Key subjects for communications with these domestic constituencies include IFI results, procurement benefits and oversight and accountability. In this regard, a shareholder's task will be greatly facilitated by a robust IF I disclosure policy. In particular, a disclosure policy with a presumption of disclosure and exceptions to disclosure contributes more than a policy that operates under the proposition that documents are presumptively restricted and only disclosable if specifically authorized. The World Bank had the latter for many years but wisely changed to the former in 2010. ${ }^{30}$ The AIIB has left the door open to this approach in Article 34(4) of the Articles of Agreement.

As shareholder representatives promote IFIs domestically, however, they need to make clear to their authorities, and in particular to the Legislative Branch, that the shareholder representatives in the Executive Branch are the sole channel for engaging with the IFI. This point is explicit in Article III(2) of the World Bank's Articles of Agreement and in Article 30(1) of the AIIB Articles of Agreement. The tendency of some legislatures may be to think of an IFI as another domestic agency, particularly when appropriating grant funds. A properly sensitized shareholder representative needs to convey the point, however, that there is no direct jurisdiction.

$30 \quad$ See World Bank, "The World Bank Policy on Access to Information" (1 July 2010). 
A similar sensitivity needs to be observed between shareholder representatives, usually governors, and IFI presidents. Astute IFI presidents and governors can develop a prudent sense of when to use the direct channel and when to use the director-level channel.

The Articles of Agreement of the World Bank also contain a provision designed to protect the international character of the Bank. Article IV, Section 10 prohibits interference in the political affairs of any member and enjoins the Bank not to be influenced in its decisions by the political character of a member. Shareholders, particularly large shareholders need to recall that, "Only economic considerations shall be relevant to ... decisions." ${ }^{31}$ There have been examples when a large shareholder has sought a particular outcome for political reasons, but the arguments in favor or in opposition must be economic in nature. The AIIB Articles contain the same principles. ${ }^{32}$ This does not mean that shareholder representatives cannot forcefully advocate with management to bring forward or to oppose key projects or initiatives, but Board members may not do so on purely political grounds.

\section{Relations with International Organizations}

International development today is a highly networked business. This is a matter of necessity because there is not enough public money available to meet all the needs. Today, the development assistance architecture requires cooperation with other IFIs. Cooperation begins with other IFIs, frequently through the Development Committee, but also through informal networks of MDв Presidents, general counsels, chief financial officers and anti-corruption units. Cooperation with the United Nations is also important. Although the World Bank secured a "declaration of independence" from the United Nations in 1947, the Bank still cooperates closely with the United Nations at many levels and on many subjects, from disaster relief and recovery to countries in conflict, to global health crises to climate change. Cooperation in economic sanctions is also addressed with the World Bank giving "due regard" to UN sanctions. Cooperation in-country with UN organizations as well as with peacekeeping missions is frequently extensive, particularly in conflict-affected states. These many points of intersection with the international community underscore the need for cultivating good relations with other international organizations as a development bank seeks to fulfill its mission.

31 See n 4, World Bank Articles of Agreement, art IV, s 10.

32 See n 5, AIIB Articles of Agreement, art 31. 


\section{Conclusion}

The role of shareholders in IFI governance has many dimensions and lies at the heart of the Articles of Agreement of an IFI. Although shareholders can have diverging interests over specific policies or operations, there actually is a remarkable degree of convergence on a series of broad themes integral to good IF I governance. This starts with a proper structuring of the relationships and distribution of power and authority among the Governors, the Executive Directors and the President and management. It extends to mobilizing resources, both capital and grants, but also includes many shared views about ensuring that the institution pursues a sustainable financial model. Shareholders have responsibility for ensuring a conducive domestic legal environment for the IFI and for promoting the IFI domestically and with other international organizations. Whether an IFI of longstanding or a new IFI like AIIB, good shareholder governance is crucial for success. 